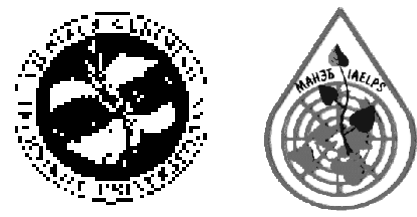

\title{
INVESTIGATION OF SOIL POLLUTION WITH HEAVY METALS IN LITHUANIAN MILITARY GROUNDS
}

\author{
Saulius Vasarevičius, Kristina Greičiūtė \\ Dept of Environmental Protection, Vilnius Gediminas Technical University, \\ Sauletekio al. 11, LT-10223 Vilnius-40, Lithuania. \\ E-mail: krist@ap.vtu.lt
}

Received 28 Jun 2004; accepted 23 Sept 2004

\begin{abstract}
Military grounds are the largest military activity territories in Lithuania. In some of them, military activities are going on for more than 100 years. Specific nature of long-term activities carried out in military grounds with military equipment, weapons, ammunition and different busters have caused the anomalies of pollution with heavy metals in some places. And what is more, in many places the environment is polluted with oil products, remains of bullets and explosive devices can be found in tactical fields, and continuous devastation has resulted in a sandy soil. The damage caused to the environment by military activities is not limited with pollution of military grounds and surrounding landscapes with different chemical substances. Water that gets into the soil destroys the remains of explosives and ammunition, filters into the deeper layers of the soil and poses a risk of pollution. The surface layer of the soil is a barrier protecting subsoil water against pollution with different chemical substances. By the extent of soil pollution, it could be judged about the risk of subsoil water pollution.

The carried out investigation was aimed at finding out the distribution of heavy metals characteristic of munition (zinc, copper, lead) in the deeper layers of the soil (up to 1-meter depth) and the trends of its changes. Tests were carried out in two major military grounds of Lithuania located in different places but used for the same purpose. The received results allowed not only to evaluate the extent of pollution with heavy metals but also to determine the peculiarities of their migration.
\end{abstract}

Keywords: military grounds, soil, pollution, heavy metals, migration.

\section{Introduction}

Heavy metals are prone to penetration into deeper layers of the soil and pose a risk to subsoil water. Subsoil and rain water poses a risk to surface water bodies. Sampling only from the surface layer of the soil is not sufficient, as unless an area is extensively used for military purposes, it is likely that high concentrations of heavy metals will not be detected. However, if several years or decades ago an area was intensively exploited, collection of heavy metal concentrations in deeper layers of the soil is possible $[1,2]$. In order to verify this statement, sampling should be done at deeper layers of the soil. During the investigation sampling was done in five places within the territory of two military grounds of Lithuania (Gaižiūnai and Kairiai). The places selected for sampling differed in the duration and intensity of their exploitation, thus the received results allowed to draw conclusions on the regularities of heavy metal migration in the soil.

\section{Description of investigated areas}

The 1st tactical field (the so-called "Sahara Desert") of Gaižiūnai Military Ground and a nearby airfield were chosen as the first test site. Some time ago two 1-meter deep borings were drilled in this area: the first one was drilled between runways of the airfield, and the second one was drilled within the area of a tactical field.

An abandoned military settlement located within the area was chosen as the second test site. In the past such a type of settlements used to have not only communal buildings but also garages, different types of storage facilities, repair shops, etc. An abandoned military settlement in Gaižiūnai Military Ground was started by the Lithuanian army before the $1^{\text {st }}$ World War; later it became a settlement of the Soviet army [3]. During the whole period, which the Soviet army stayed there, the area was intensively exploited what could result in negative impact on the environment. At present the area is 
not exploited any more, it contains only the remains of the former settlement. For the above mentioned reasons it is likely that pollution with heavy metals will not be extensive in the surface layer of the soil; however, collection of pollutants is possible in deeper layers [4].

An abandoned missile air base settlement located within Kairiai Military Ground was selected as the third test site. In the Soviet period military activities were held there. There were barracks, missile bunkers, car repair shops, headquarters and other buildings in the area [3]. The above-mentioned military activities could cause soil pollution with heavy metals, thus the existing state of soil should be examined. Within the area of the abandoned missile air base settlement, a 1-meter deep bore was drilled close to the abandoned missile bunker.

A pine forest growing within the area of Kairiai Military Ground was selected as the fourth test site. Visually it is an area not affected by military activities; however, in reality in the Soviet period buildings intended for similar activities were present there. The period when this site was unexploited is longer than that of the abandoned missile air base settlement in Kairiai Military Ground, thus its is likely that higher concentrations of heavy metals, if any, will be found in deeper layers of the soil $[5,6]$. The concentration of heavy metals in soil strongly depends on the features of ground. It is very important to point out the type and conditions of each soil type (Table).

Sampling was performed at a different depth in the same place. A 1-meter deep bore was drilled for that (Fig 1). The surface layer of the soil is considered to be a datum-point (a depth of 0-5 cm). Then, with the help of stainless-metal trowel, soil samples were taken every $20 \mathrm{~cm}$ (by taking several samples from all the walls of the bore and mixing them). Samples were put into small sacks; each sample was given a specific number.

Samples put into special fabric sacks (approximately $500 \mathrm{~g})$ were taken to the Laboratory of Environmental

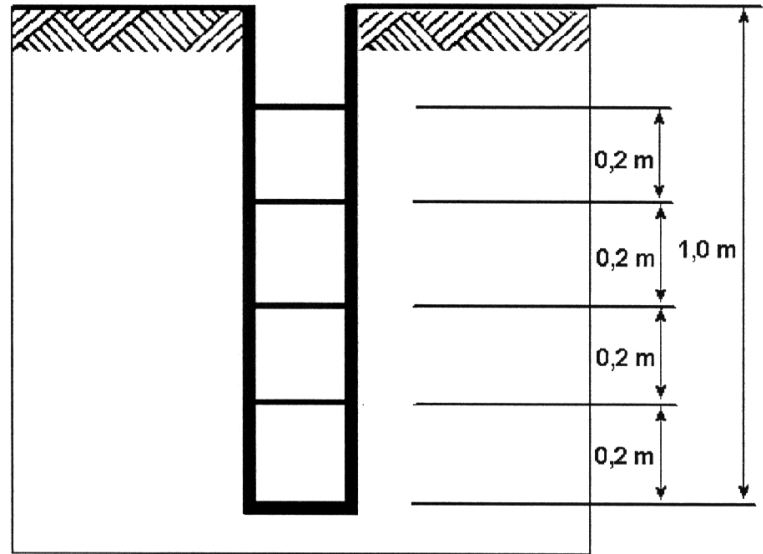

Fig 1. Scheme of sampling performed for the analysis of heavy metal pollution in deeper layers of the soil

Protection Department in Vilnius Gediminas Technical University where they were analysed by atomic absorption spectroscopy.

Soil samples were desiccated in a dry non-dusty place then pulverized and sieved (sieve with the mesh of $0,81 \mathrm{~mm}^{2}$ ) to remove little stones and organic admixtures.

$30-40 \mathrm{~g}$ of each sample was desiccated at a temperature of $105{ }^{\circ} \mathrm{C}$ for 2 hours and then sieved for the second time (sieve with the inner diameter of $1 \mathrm{~mm}$ ). Then the desiccation procedure was repeated (samples were kept at a temperature of $105^{\circ} \mathrm{C}$ for $30 \mathrm{~min}$ ). When the samples were cooled, 20 grams of each one were taken and placed into a bulb of $500 \mathrm{ml}$. The samples were poured with an admixture of $\mathrm{HNO}_{3}$ and $\mathrm{HCl}$, both concentrated (proportion 1:3), and boiled for $15 \mathrm{~min}-$ utes. Hot solutions were filtered into a $100 \mathrm{ml}$ bulb. Solution of each sample was analysed with an atomic absorption spectrometer 210 VGP.

Layer description in the bores drilled in Gaižiūnai and Kairiai military grounds

\begin{tabular}{|c|c|c|c|c|}
\hline \multirow{2}{*}{ No and bore location } & \multirow{2}{*}{ Layer No } & \multicolumn{2}{|c|}{ Ground features } & \multirow{2}{*}{$\begin{array}{l}\text { Layer } \\
\text { thickness }(\mathbf{m})\end{array}$} \\
\hline & & Soil type, colour, etc & Physical condition of soil & \\
\hline \multirow{3}{*}{$\begin{array}{l}\text { 1. Airborne airfield of Gaižiūnai } \\
\text { Military Ground }\end{array}$} & 1. & Vegetative soil & - & 0,2 \\
\hline & 2. & Fine sand, yellowy & Light density & 0,5 \\
\hline & 3. & Fine sand, yellowy & Medium density & 0,3 \\
\hline \multirow{2}{*}{$\begin{array}{l}\text { 2. The 1st tactical field of Gaižiūnai } \\
\text { Military Ground }\end{array}$} & 1. & Fine sand, yellowy & Light density & 0,5 \\
\hline & 2. & Sand medium sized, grey & Dense & 0,5 \\
\hline \multirow{3}{*}{$\begin{array}{l}\text { 3. Military settlement of Gaižiūnai } \\
\text { Military Ground }\end{array}$} & 1. & Vegetative soil & - & 0,4 \\
\hline & 2. & Sandy loam, rosy-brown & Plastic & 0,4 \\
\hline & 3. & Sandy loam, rosy brown & Solid & 0,2 \\
\hline \multirow{3}{*}{$\begin{array}{l}\text { 4. Abandoned missile air base } \\
\text { settlement of Kairiai Military } \\
\text { Ground }\end{array}$} & 1. & Vegetative soil & - & 0,2 \\
\hline & 2. & Clay loam, rosy-brown & Solid plastic & 0,4 \\
\hline & 3. & Clay loam, brown & Solid & 0,4 \\
\hline \multirow{3}{*}{$\begin{array}{l}\text { 5. Pine forest of Kairiai Military } \\
\text { Ground }\end{array}$} & 1. & Vegetative soil & - & 0,2 \\
\hline & 2. & Dusty sand, dark-grey, peaty & Light density & 0,5 \\
\hline & 3. & Fine sand, yellow & Medium density & 0,3 \\
\hline
\end{tabular}




\section{Investigation results}

The results received on the first site (airfield of Gaižiūnai Military Ground) have revealed the tendency of heavy metal migration.

As seen in Fig 2, the concentrations of all the analysed metals $(\mathrm{Zn}, \mathrm{Cu}, \mathrm{Pb})$ were higher in deeper layers than on the surface. No sample had concentrations of zinc and copper exceeding the background concentrations (background concentration of zinc for sandy and sandy loam grounds is $26 \mathrm{mg} / \mathrm{kg}$, and that of copper is $8,1 \mathrm{mg} / \mathrm{kg}$ ) [7, 8]. Still it is obvious that the concentrations of these metals are higher in deeper layers of the soil (difference between zinc and copper concentrations measured at the surface and at a 1-meter depth, respectively, were 38 and $58 \%$ ). The situation is a bit different in the case of the results of measuring lead pollution. Its concentration also tends to grow up going deeper (the difference between a maximum concentration at a 1-meter depth and a minimum concentration at the surface is $53 \%$ ); however, a maximum measured concentration at a 1-meter depth is slightly higher (20\%) than the background concentration $[7,8]$. Considering the error of heavy metal measuring, which is $20 \%$, it could be stated that meantime the airfield of Gaižiūnai Military Ground is not polluted with the above mentioned heavy metals. As mentioned in the description of the methods, a bore was drilled between the runways of the airfield, and the airfield has not been used for a while. An explanation for higher concentrations of heavy metals in deeper layers of the soil could be the fact that due to previous extensive exploitation of the airfield, materials that could cause heavy metal pollution were emitted into the environment. In the course of time, these substances migrated into deeper layers of the soil and concentrated there [9]. After the exploitation of the airfield was stopped, no more pollutants were emitted, thus the concentrations of heavy metals found in the surface layer of the soil were very low.

The results received on the second test site (the $1^{\text {st }}$ tactical field) tended to be slightly different. The same as on the first site, the concentrations of zinc or copper did not exceed the background values (respectively, 26 and $8,1 \mathrm{mg} / \mathrm{kg}$ ), they were even much lower [7,8]. As seen in Fig 3 , the highest concentrations of zinc were detected at a depth of $0,4 \mathrm{~m}$, while the lowest ones - at a depth of $1 \mathrm{~m}$.

On the contrary, the highest concentrations of copper were found on the surface of the soil and at a depth of 1 meter. Such an uneven distribution of pollutant prevents us from drawing specific conclusions on the trends of pollution. It should be mentioned that exclusively sandy soil prevails in the $1^{\text {st }}$ tactical field, thus pollutant assimilation, stimulated by plants, and the soil self-purification process take a longer time. This fact could explain higher concentrations of zinc and copper at a depth of 0 to $0,4 \mathrm{~m}$. But it is also known that a sandy soil is less sensitive to pollution with heavy metals, as the migration processes are much faster than in clayey soils [5]. This statement was proved by the analysis of concentrations of another metal, i e lead. In this case the situation is similar to that on the $1^{\text {st }}$ test site. The figure clearly shows that the highest concentration of lead was found at a depth of $0,5-1 \mathrm{~m}$ (a maximum one ex- ceeds the background concentration by $32 \%$ ), while the concentration on the surface is minimal. Even considering the error in determining heavy metals, which is equal to $20 \%$, it could be stated that lead concentrations in deeper layers of the soil reach the risk limit. Such an uneven distribution of heavy metals in the depth bore in the $1^{\text {st }}$ tactical field could also be explained by the fact that the composition of explosive devices and ammunition used in this area has changed, and now the content of lead is lower, and that of copper and zinc is higher. The fact that at present the exploitation of the area is less extensive than that 20 or 30 years ago and that the nature of military activities in this area has changed is also worth mentioning. If in the past the training of firing as well as other types of training were intense there, nowadays explosion training is carried out in the area. Zinc and copper are the main components of munition, while lead is characteristic of cartridge-cases. It could be that these facts predetermined uneven distribution of concentrations.

The results of the analysis carried out in the depth bore at the military settlement of Gaižiūnai Military Ground have revealed an entirely opposite situation, if compared with that in the depth bore drilled near the air field. If in the previous case the highest concentrations of heavy metals were found in deeper layers of the soil, in the latter situation it was an opposite case: the highest concentrations of zinc, copper and lead were found in the surface layer of the soil. Concentrations of neither zinc, nor copper exceeded the background value, they were even much lower (Fig 4). Maximum lead concentration found on the surface of the soil was $18 \mathrm{mg} / \mathrm{kg}$, while the background concentration of lead characteristic of sandy and sandy loam soils is $15 \mathrm{mg} / \mathrm{kg}[7,8]$. Thus, such results allow to state that there is no risk of heavy metal pollution in the territory of the abandoned military settlement of Gaižiūnai Military Ground. It could be stated that heavy metal pollutants concentrate in the surface layer of the soil; however, no military activities have been carried out in this area for more than a decade, thus, it is hardly believable that concentrations of heavy metals would increase.

It is obvious that in Kairiai Military Ground soil pollution with heavy metals has reached an inadmissible level. As seen in Figs 5 and 6, the highest concentrations were found in the surface layer of the depth bore in the abandoned missile air base settlement of Kairiai Military Ground, the concentrations get lower in deeper layers. The concentrations of zinc and copper at a depth of $1 \mathrm{~m}$ are much lower than the background ones, and zinc concentrations at such a depth exceed the background concentration by $67 \%$ even at such a depth. In the surface layer of the soil, in the same place where samples of deeper layers had been taken, the concentration of lead was $390 \mathrm{mg} / \mathrm{kg}$ (while the background concentration of lead is $15 \mathrm{mg} / \mathrm{kg}$ ).

Such high concentrations were not found in any of the samples taken in the depth bores of Gaižiūnai Military Ground.

Comparison of the results received in both abandoned military settlements (in Gaižiūnai and Kairiai) reveals a similar trend of pollutant distribution: the highest concen- 


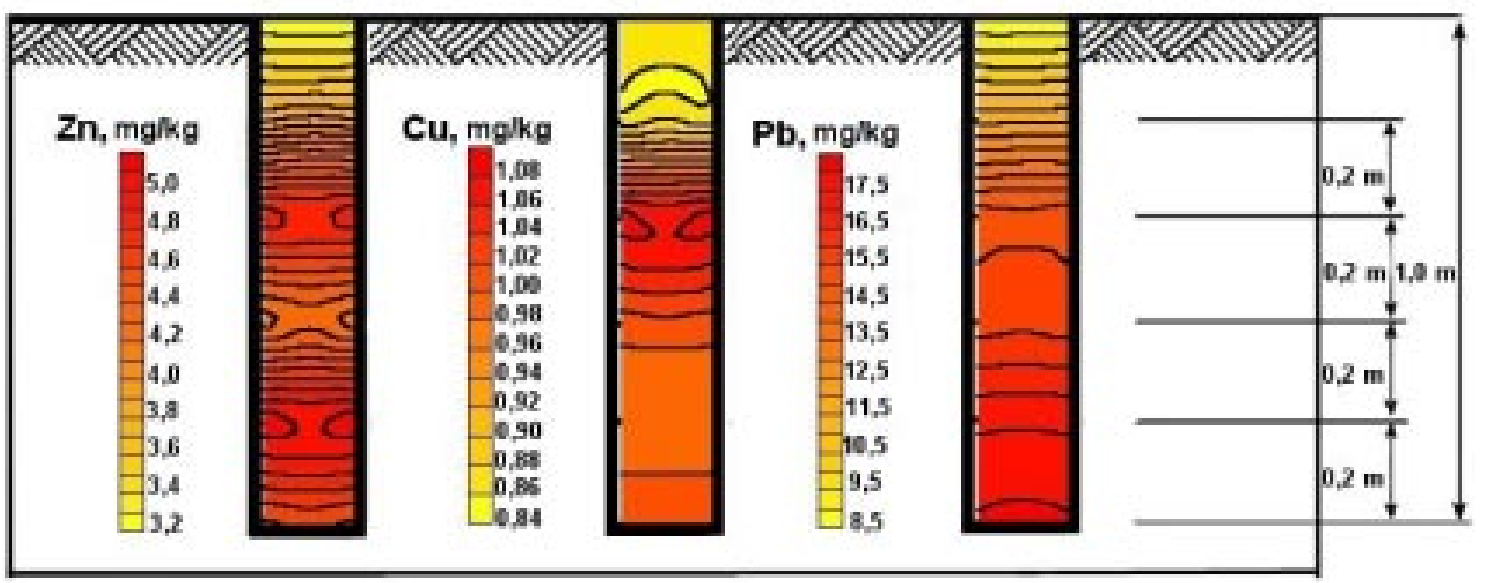

Fig 2. Concentrations of heavy metals in the depth bore of the airfield of Gaižiūnai Military Ground (the depth $0-1 \mathrm{~m}$ )

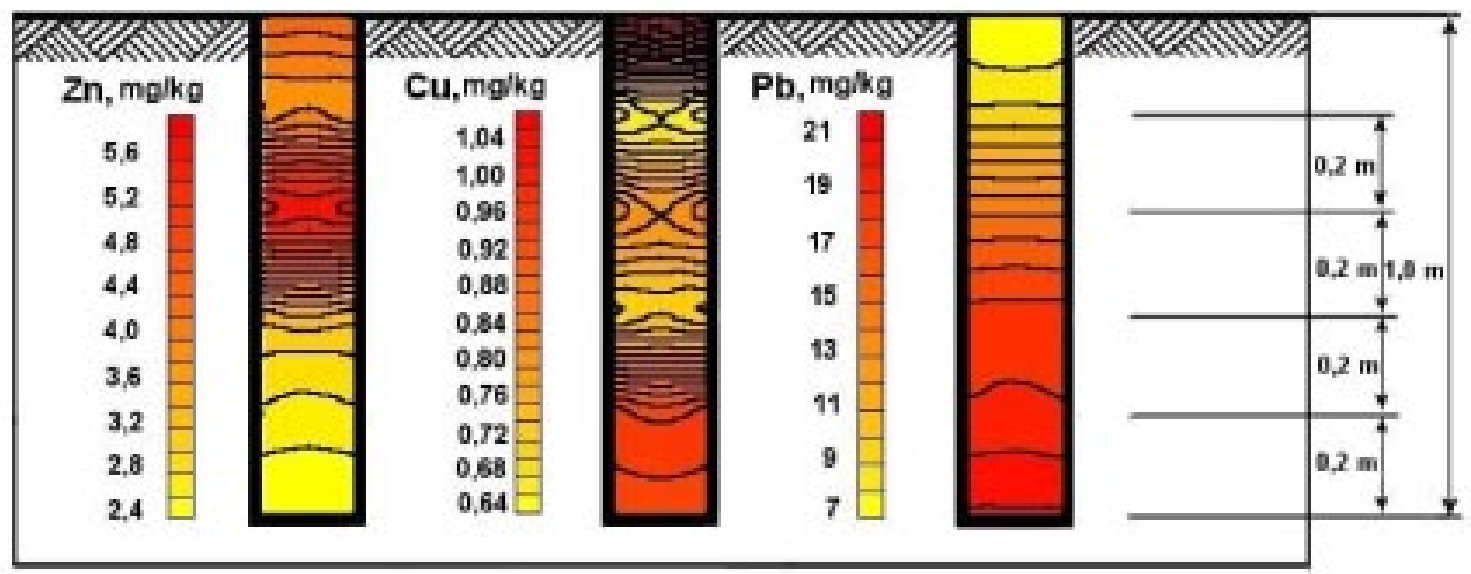

Fig 3. Concentrations of heavy metals in the depth bore of the $1^{\text {st }}$ tactical field ("Sahara Desert") of Gaižiūnai Military Ground (the depth $0-1 \mathrm{~m}$ )

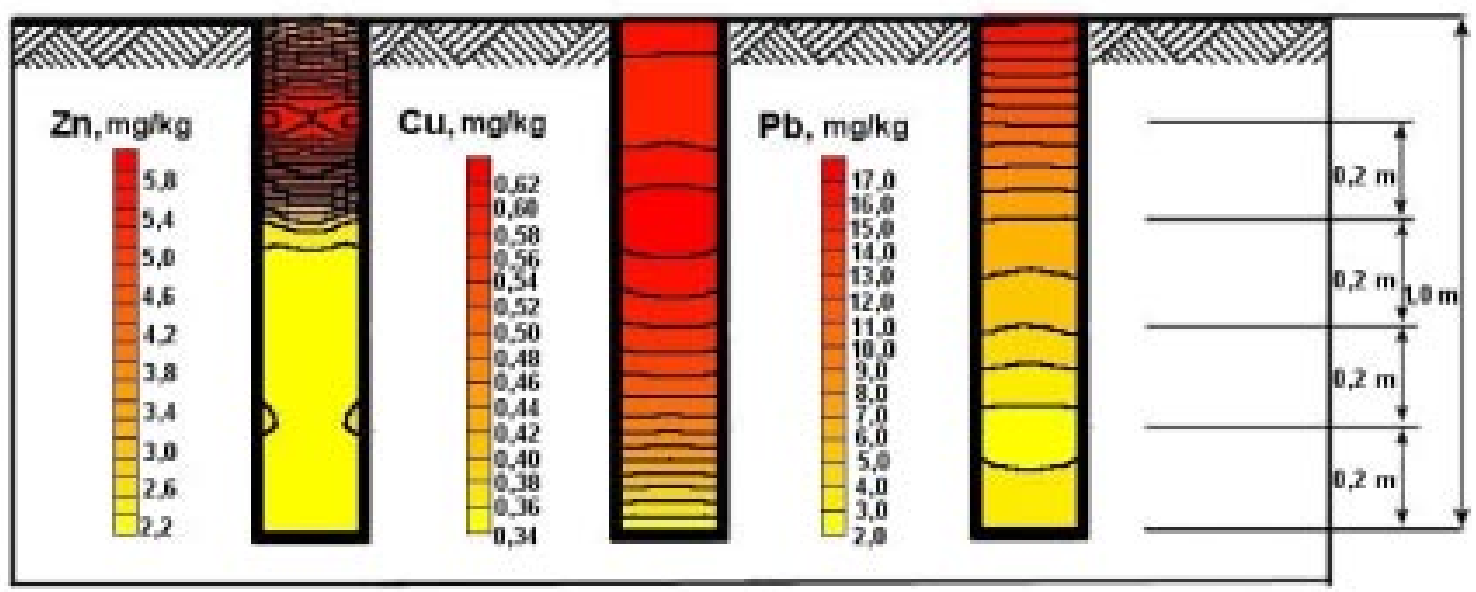

Fig 4. Concentrations of heavy metals in the depth bore in the territory of an abandoned military settlement in Gaižiūnai Military Ground (the depth $0-1 \mathrm{~m}$ ) 


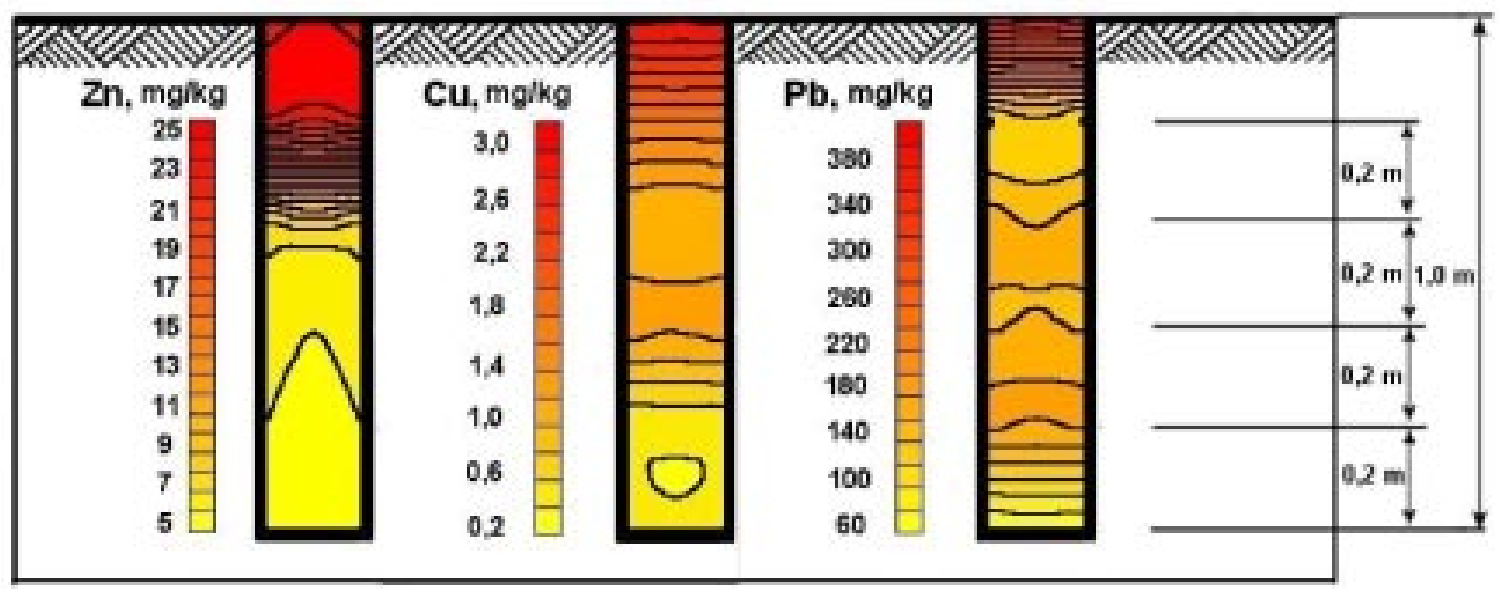

Fig 5. Concentrations of heavy metals in the depth bore in the territory of an abandoned military settlement in Kairiai Military Ground (the depth $0-1 \mathrm{~m}$ )

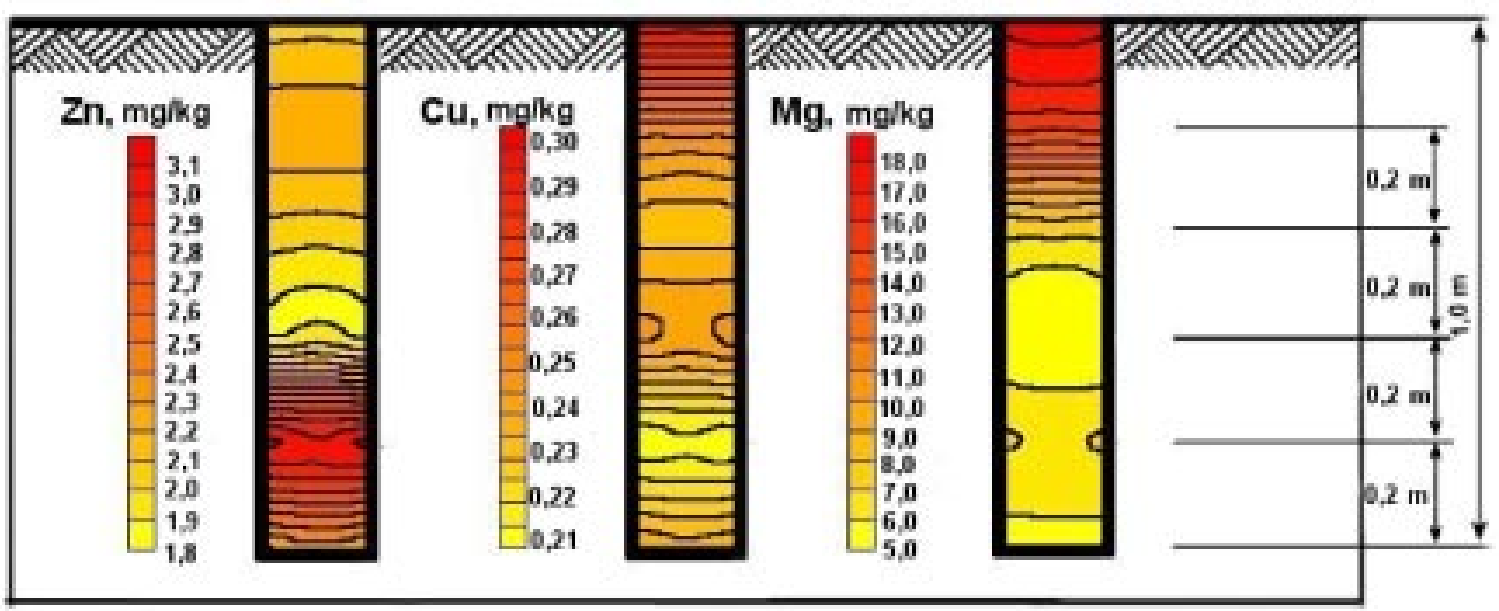

Fig 6. Concentrations of heavy metals in the depth bore in the territory of a pine forest in Kairiai Military Ground (the depth $0-1 \mathrm{~m})$

trations of pollutants are found in the surface layer of the soil, and the concentrations become lower in deeper layers.

Analysis of samples taken in the pine forest of Kairiai Military Ground revealed a very uneven distribution of pollutants. The highest concentrations were found at a depth of $0,8-1,0 \mathrm{~m}$; however, they were much lower than the background ones (background concentration of zinc is $26 \mathrm{mg} / \mathrm{kg}$ ) [8]. Such a distribution of zinc concentrations was also found in the depth bore in the airfield of Gaižiūnai Military Ground. On the contrary, concentrations of copper and lead were higher in the surface layer of the soil but they did not exceed the background values (background concentrations of copper and lead for sandy and sandy loam soils respectively are 8,1 and $15 \mathrm{mg} / \mathrm{kg}$ ). The same trend is seen in the depth bores drilled in the abandoned military settlements of Gaižiūnai and Kairiai military grounds. No military activities have been carried out in the analysed territories, the territory is planted with pines, thus, it could be stated that pollution with heavy metals will not increase, and in the course of time it will become lower due to the self-purification process of the soil.

\section{Conclusions}

The investigation has revealed that in the areas that at present are not extensively exploited for military purposes the concentrations of pollutants are found in deeper layers of the soil ( $1 \mathrm{~m}$ deep). This could be explained by pollutant migration in the course of time.

The results received in the tactical field of Gaižiūnai Military Ground have revealed that concentrations of individual metals are different at a different depth. Distribution of copper and zinc concentrations is uneven, and extra investigation is necessary to find out the trends of pollutant migration. Lead concentrations are the biggest at a depth of $1 \mathrm{~m}$ and less - at a depth of $0,1 \mathrm{~m}$ showing that lead pollution has stoped; besides, that could be explained by changed composition of ammunition and the purpose of the area [10].

The results received at both military settlements of the examined military grounds have revealed that the highest concentrations of heavy metals are found in the surface layer of the soil. In the abandoned military settlement of Kairiai Military Ground the highest concentrations of lead 
have exceeded the background values ten times. Such results indicate that the soil pollution level in the above mentioned areas is extremely high, and self-purification processes are very slow. Anyway, these areas are not used for military purposes any more, so further soil pollution with heavy metals has stopped.

\section{References}

1. Baltrènas, P.; Ignatavičius, G. Strategy of Military Land Reuse in Lithuania. Approaches to the Implementation of Environment Pollution Prevention Technologies at Military Bases. RTO Proceedings, NATO Publishing: Cedex (France), Vol 39, No 12, 2000, p 1-7.

2. Baltrènas, P.; Oškinis, V.; Ignatavičius, G.; Kumpienė, J. Mechanical disturbance of soils in the field of trainings in the Lithuanian central firing ground in Pabrade and possibilities of environmental protection improving. Environmental Engineering (Aplinkos inžinerija), Vol IX, No 2, 2001, p 103-109.

3. Baubinas, R.; Taminskas, J. Natural resources using for military concerns: ecological consequences. Geological Survey of Lithuania. Vilnius, 1997-1998. 258 p.

4. Benker, K. W. Removing metals from soil. Civil Engineering, Vol 65, No 10, 1995, p 69-71.

5. Brady, N. C. The Nature and Properties of Soils $\left(10^{\text {th }}\right.$ Edition). MacMillan: London, 1990. 542 p.

6. Ceburnis, D., Steinnes, E., Kvietkus, K. Estimation of metals uptake efficiencies from precipitation in mosses in Lithuania. Chemosphere, Vol 38, No 2, 1999, p 445-455.

7. Kadūnas, V., and others. Geochemical atlas of Lithuania. Geological survey of Lithuania: Vilnius, 1999, 162 p.

8. Lithuanian Standard of Hygiene HN 60:2004. Maximum alowed concentrations of hazardous chemicals in soil, Lithuanian Ministry of Health, $8^{\text {th }}$ of March, 2004.

9. Mazvila, J. Heavy metals in Lithuanian soils and plants, Lithuanian Academy of Agriculture: Kaunas, 2001. 343 p.

10. Renner, M. Assessing the Military's War on the Environment. State of the World: New York-London, 1991.

\section{GRUNTŲ TARŠOS SUNKIAISIAIS METALAIS TYRIMAS LIETUVOS KARINIUOSE POLIGONUOSE}

\section{S. Vasarevičius, K. Greičiūtė}

$\mathrm{S}$ a $\mathrm{n} \mathrm{tr}$ a u k a

Didžiausios karinès teritorijos Lietuvoje - kariniai poligonai. Kai kuriuose iš jų karinè veikla vyksta jau daugiau nei 100 metu. Dẻl specifinès veiklos, ilgus metus vykdomos kariniuose poligonuose, karinès technikos, ginklų, amunicijos bei įvairių sprogstamujų užtaisų naudojimo kai kur susiformavo užterštumo sunkiaisiais metalais anomalijos. Be to, daug kur aplinka užteršta naftos produktais, taktinių mokymų laukuose mètosi kulkų ir sprogstamujų užtaisų liekanos, o dèl nuolatinių pažeidimų vyrauja smèlingas gruntas. Žala aplinkai dèl karinès veiklos - tai ne tik poligonų bei aplinkinių teritorijų dirvožemio užtarša įvairiomis cheminėmis medžiagomis. Vanduo, patenkantis i dirvožemi, ardo sprogmenų ir amunicijos liekanas, filtruojasi i gilesnius dirvožemio sluoksnius. Kyla jų užtaršos pavojus. Paviršinis dirvožemio sluoksnis yra barjeras, saugantis gruntinius vandenis nuo užtaršos ịvairiomis cheminèmis medžiagomis. Pagal dirvožemio užterštumą galima spręsti apie gruntinių vandenų užtaršos pavojų.

Atlikto tyrimo tikslas buvo nustatyti sunkiujuc metalų, būdingų sprogstamiesiems užtaisams (cinko, vario, švino), pasiskirstymą gilesniuose (iki $1 \mathrm{~m}$ ) dirvožemio sluoksniuose bei jų koncentraciju kitimo tendencijas. Tyrimai buvo atlikti dviejuose didžiausiuose tos pačios paskirties Lietuvos poligonuose, esančiuose skirtingose vietovèse. Gautieji rezultatai leido ivvertinti ne tik taršos sunkiaisiais metalais išplitimą paviršiniame dirvožemio sluoksnyje, bet ir nustatyti migracijos ypatumus.

Raktažodžiai: kariniai poligonai, neigiamas poveikis, dirvožemis, tarša, sunkieji metalai, migracija.

\section{ИССЛЕДОВАНИЕ ЗАГРЯЗНЕННОСТИ ПОЧВЫ ТЯЖЕЛЫМИ МЕТАЛЛАМИ НА ВОЕННЫХ ПОЛИГОНАХ ЛИТВЫ}

\section{С. Васарявичюс, К. Грейчюте}

$\mathrm{P}$ е 3 ю $\mathrm{M}$ e

Самыми крупными по занимаемой ими площади военными территориями в Литве являются военные полигоны. Чаще всего они находятся сравнительно далеко от городов и поселков, в окружении лесов с ценными панорамами и биологическими ресурсами. На территориях полигонов в Гайжюнай и Кайряй военные действия проводятся уже в течение 100 лет. Из-за специфики деятельности, проводимой на полигонах, интенсивного использования военной техники, оружия и взрывчатых материалов кое-где сформировались аномалии загрязненности почвы тяжелыми металлами. На многих территориях почва также загрязнена нефтепродуктами, на полях тактических учений валяются остатки пуль и взрывчатых устройств. Из-за многочисленных повреждений преобладает песчаный грунт. Ущерб, наносимый природе военными действиями, не ограничивается загрязнением почвы на территориях полигонов и их окрестностей разными химическими материалами. Вода, попадающая на поверхность земли, проходит через слои загрязненного грунта, растворяет нефтепродукты и тяжелые металлы и, всасываясь, создает опасность загрязнения грунтовых вод. Поверхностный грунт обладает свойством удерживать загрязняющие вещества и представляет собой барьер, который предохраняет грунтовые воды от загрязнения различными химическими веществами. Исследованием была установлена не только загрязненность тяжелыми металлами поверхностного слоя почвы, но и миграция металлов.

Ключевые слова: военные полигоны, негативное влияние, почва, загрязненность, тяжелые металлы, миграция. 